\title{
ACAROLOGY
}

\section{Population Dynamics of Aceria guerreronis Keifer (Acari: Eriophyidae) and Associated Predators on Coconut Fruits in Northeastern Brazil}

\author{
Aleuny C. Reis ${ }^{1}$, Manoel G.C. Gondim Jr. ${ }^{1}$, Gilberto J. De Moraes², Rachid Hanna ${ }^{3}$, Peter \\ Schausberger ${ }^{4}$, Late E. Lawson-Balagbo ${ }^{4}$ and Reginaldo Barros ${ }^{1}$ \\ ${ }^{1}$ Depto. Agronomia, Univ. Federal Rural de Pernambuco, 52171-900, Recife, PE, Brazil \\ ${ }^{2}$ Depto. Entomologia, Fitopatologia e Zoologia Agrícola, ESALQ - Univ. São Paulo, C. postal 9 , \\ 13.418 -900, Piracicaba, SP, Brazil \\ ${ }^{3}$ International Institute of Tropical Agriculture, Biological Control Centre for Africa, 08 BP 0932, Cotonou, Benin \\ ${ }^{4}$ Dept. of Applied Plant Sciences and Plant Biotechnology, Institute of Plant Protection, Univ. of Natural \\ Resources and Applied Life Sciences, Vienna, Austria
}

Neotropical Entomology 37(4):457-462 (2008)

Dinâmica Populacional de Aceria guerreronis Keifer (Acari: Eriophyidae) e Predadores Associados em Frutos de Coqueiro no Nordeste do Brasil

RESUMO - Aceria guerreronis Keifer pode causar danos severos em coqueiro em vários países ao redor do mundo. Raros estudos têm sido conduzidos para determinar os ácaros predadores associados com A. guerreronis no Brasil. O objetivo deste estudo foi avaliar a prevalência de $A$. guerreronis e dos predadores associados nas brácteas e na superfície dos frutos abaixo delas, durante 12 meses, em frutos de coqueiro adulto ao longo da costa de Alagoas, Paraíba e Pernambuco, no Nordeste do Brasil. Ácaros de 10 famílias foram encontrados, contudo a espécie mais abundante foi A. guerreronis, correspondendo a $99,5 \%$ dos ácaros coletados. Dentre as espécies predadoras prevaleceram os ácaros Phytoseiidae Neoseiulus baraki (Athias-Henriot) e Neoseiulus paspalivorus (De Leon). Estes são achatados e possuem pernas curtas, características que lhes permitem invadir o habitat ocupado por A. guerreronis. Outros predadores foram encontrados, mas em número bem menor, provavelmente pela dificuldade que têm em penetrar nas áreas comumente habitadas por A. guerreronis. Contudo, essas espécies têm potencial de predação sobre o ácaro quando este sai de seu habitat preferido para se dispersar. Não se observaram correlações significativas entre os níveis de fatores abióticos e os níveis populacionais de A.guerreronis ou dos fitoseídeos associados a essa espécie. Isso provavelmente se deu devido aos efeitos simultâneo e conflitante daqueles fatores sobre os ácaros no campo, ou a diferenças significativas entre os fatores climáticos medidos no ambiente e aqueles prevalentes no habitat ocupado por A. guerreronis.

PALAVRAS-CHAVE: Ácaro do coqueiro, ácaro predador, controle biológico, Phytoseiidae

ABSTRACT - Aceria guerreronis Keifer can cause severe damage to coconuts in several countries around the world. Rare studies have been conducted to determine the predatory mites associated with $A$. guerreronis in Brazil. The study evaluated the prevalence of $A$. guerreronis and associated predators on the bracts and on the surface of the fruits underneath the bracts, for 12 months, on coconut palms grown along the coast of the States of Alagoas, Paraíba and Pernambuco, Northeastern Brazil. Mites of 10 families were found, but by far the most abundant species was A. guerreronis, corresponding to $99.5 \%$ of the mites collected. The prevailing species amongst the predators were the Phytoseiidae mites Neoseiulus baraki (AthiasHenriot) and Neoseiulus paspalivorus (De Leon). These are flat mites that have short limbs, characteristics that allow them to invade the main habitat occupied by $A$. guerreronis. Other predators were found, but in low numbers, due mainly to their difficulty in reaching the fruit areas most inhabited by A. guerreronis. However, these mites could prey on that pest when it leaves its preferred habitat to disperse. No significant correlations were observed between the levels of abiotic factors and the population levels of $A$. guerreronis or of the phytoseiids associated with it. This probably occurred due to the simultaneous and conflicting effects of those factors on the mites in the field, or to significant differences between the climatic factors measured in the environment and those prevailing in the habitat occupied by A. guerreronis.

KEY WORDS: Coconut mite, predator mite, biological control, Phytoseiidae 
Five mite species of the superfamily Eriophyoidea have been reported on coconut palm in Brazil, namely Amrineus cocofolius Flechtmann, Aceria guerreronis Keifer, Retracrus johnstoni Keifer, Notostrix attenuata Keifer and Notostrix nasutiformes Gondim Jr., Flechtmann \& Moraes (Santana \& Flechtmann 1998, Gondim Jr. et al. 2000). Of these, only A. guerreronis is considered of significant importance to the crop in the country, where it was reported for the first time in mid 1960's (Robbs \& Peracchi 1965, Aquino et al. 1968). In many countries where coconut is an important crop, this mite may cause severe damage, reducing yield up to $80 \%$ because of induced fruit drop and/or reduction of fruit size and quality (Moore et al. 1989, Haq et al. 2002).

Colonies of $A$. guerreronis are mostly found in the meristematic region of the fruits, under the perianth (Fernando et al. 2003). The colonies usually start to develop when fruits are still small, resulting in the appearance of discolored areas on the epidermis that frequently become larger and necrotic, cracking longitudinally and eventually producing an exudate (Haq et al. 2002). In addition to fruit damage, when first reported in Brazil, this mite was mentioned to attack the growing tip of plantlets, turning it dark brown and often causing death of attacked plants (Aquino et al.1968).

Several predatory mites have been reported in association with A. guerreronis on coconuts. Those belong to the families Ascidae, Bdellidae, Cheyletidae and, mainly, Phytoseiidae (Howard et al. 1990, Cabrera et al. 1992, Moraes et al. 2004, Lawson-Balagbo et al. 2007). Studies to identify the predatory mites associated with that pest in Brazil are scarce; the only efforts to determine those mites correspond to Navia et al. (2005) and to a recent survey by Lawson-Balagbo et al. (2007). However, nothing is known about the prevalence of A. guerreronis and its predators on coconuts in the field.

This study is part of an ongoing project concerning the classical biological control of A. guerreronis in Africa, conducted in collaboration between the International Institute of Tropical Agriculture (IITA), University of Natural Resources and Applied Life Sciences (BOKU), Universidade Federal Rural de Pernambuco (UFRPE) and Escola Superior de Agricultura "Luiz de Queiroz" (ESALQ). The objective was to evaluate the fluctuation of the population of $A$. guerreronis and its associated predators over a 12 months period on coconut palms grown along the coast of the States of Alagoas, Paraíba and Pernambuco.

\section{Material and Methods}

Sampling. Monthly sampling were conducted in a coconut field in each of the following localities: Itamaracá, State of Pernambuco $\left(07^{\circ} 46^{\prime} 18.8^{\prime \prime} \mathrm{S}, 34^{\circ} 52^{\prime} 38.8^{\prime \prime} \mathrm{W}\right)$; Maragogi, State of Alagoas ( $\left.08^{\circ} 58^{\prime} 43.4^{\prime \prime} \mathrm{S}, 35^{\circ} 11^{\prime} 10.4^{\prime \prime} \mathrm{W}\right)$ and Pitimbu, State of Paraíba $\left(07^{\circ} 28^{\prime} 15.7^{\prime \prime}\right.$ 'S, 34 $\left.48^{\prime} 27.3^{\prime \prime} \mathrm{W}\right)$, between 25 January and 15 December, 2005. The three plantations were rain fed and planted with hybrid coconut trees. Plants were about $12 \mathrm{~m}$ high and 20 years old. The trees were not fertilized but did not show noticeable nutritional deficiencies.

On each sampling date, 10 nuts of the third and fourth coconut bunches from the first totally open inflorescence were taken from each of three randomly selected trees. Fruits were $6-7 \mathrm{~cm}$ in diameter and $9-11 \mathrm{~cm}$ in length; they were placed in a cool box $\left(10-15^{\circ} \mathrm{C}\right)$ for transport to the laboratory, where they were maintained in a refrigerator until processed, within seven days.

Sample processing. The bracts of each fruit were removed and their lower and upper surfaces as well as the surface of the fruit underneath them were examined under a stereomicroscope, collecting all mites eventually found in this process. Subsequently, 20 to 30 eriophyid mites and all mites of other groups found on the 10 fruits of each tree were slide mounted for subsequent identification and quantification. The remaining mites of those fruits were transferred with a brush to a vial containing $3 \mathrm{ml}$ of $70 \%$ alcohol and a drop of Tween 80 (to break superficial tension); the container was vigorously shaken and $1 \mathrm{ml}$ of the liquid with the mites was immediately transferred to a Peterson's slide to determine the number of mites. Total number of mites per fruit was then estimated by extrapolation, multiplying by three the number of mites of each group found. This method is considered to be more precise than those used previously by Fernando et al. (2003) and Siriwardena et al. (2005).

Data analyses. The number of each mite species was determined for each sampling date. Mounford similarity indexes between fields were determined (Silveira Neto et al. 1976); those indexes estimated the similarity between pairs of fields in relation to the proportion of species that they share. Species richness index of each locality was calculated as the asymptote value of a function fitted to the respective smoothed species accumulation curve, provided by EstimateS (Colwell 2004). Meteorological data were obtained from "Secretaria de Recursos Hídricos do Estado de Pernambuco" and from "Instituto Nacional de Meteorologia (INMET), and referred to meteorological stations closest to the sites where the study was conducted (Itamaracá, $5 \mathrm{~km}$; Maragogi, 20 $\mathrm{km}$; Pitimbu, $30 \mathrm{~km}$ ).

Simple correlations between levels of abiotic or biotic factors determined in this study and the population levels of $A$. guerreronis were determined using the PROC CORR program of SAS package (SAS Institute 1999-2001). Multiple regressions between A. guerreronis population levels and abiotic factors were determined using the PROC REG program of the same package.

\section{Results and Discussion}

Mites of 10 families were found in this study (Table 1). The numbers of species of the represented families were: Phytoseiidae (7); Ascidae (5); Bdellidae and Tarsonemidae (3); Acaridae, Cheyletidae and Tydeidae (2); Ebertiidae, Eriophyidae and Histiostomatidae (1).

Species richness indices did not differ between fields (Table 1). Thirteen taxa were found in all three localities. Exclusive taxa (those found in just one site), were found in very low numbers. Mounford similarity indices indicated considerable resemblances between the three fields in 
Table 1. Total number specimens of mite species found on fruits of C. nucifera, between January and December 2005, and indices of species richness in three localities of northeastern Brazil.

\begin{tabular}{|c|c|c|c|}
\hline Mite taxon & Maragogi - AL & Itamaracá - PE & Pitimbu - PE \\
\hline \multicolumn{4}{|l|}{ Acaridae } \\
\hline Neotropacarus sp. & - & 2 & 2 \\
\hline Tyrophagus putrescentiae (Schrank) & 27 & 5 & 72 \\
\hline \multicolumn{4}{|l|}{ Ascidae } \\
\hline Asca foxi DeLeon & - & 2 & - \\
\hline Lasioseius subterraneus Chant & - & 1 & 6 \\
\hline Proctolaelaps bickleyi (Bram) & 15 & 12 & 30 \\
\hline Proctolaelaps coffeae Karg & - & 1 & - \\
\hline Proctolaelaps n.sp. & 13 & 9 & 2 \\
\hline \multicolumn{4}{|l|}{ Bdellidae } \\
\hline Bdella distincta (Bake \& Balogh) & 4 & 6 & 46 \\
\hline Cyta sp. & - & - & 3 \\
\hline Spinibdella sp. & - & 1 & - \\
\hline \multicolumn{4}{|l|}{ Cheyletidae } \\
\hline Hemicheyletia sp. & 2 & - & - \\
\hline Mexecheles sp. & 1 & - & - \\
\hline \multicolumn{4}{|l|}{ Ebertiidae } \\
\hline Suidasia sp. & - & 1 & - \\
\hline \multicolumn{4}{|l|}{ Eriophyidae } \\
\hline Aceria guerreronis Keifer & 473,073 & 361,560 & 379,788 \\
\hline \multicolumn{4}{|l|}{ Histiostomatidae } \\
\hline Histiostoma sp. & 56 & 38 & 63 \\
\hline \multicolumn{4}{|l|}{ Phytoseiidae } \\
\hline Amblyseius aerialis (Muma) & - & - & 1 \\
\hline A. largoensis (Muma) & 20 & 18 & 32 \\
\hline Euseius alatus DeLeon & 1 & - & - \\
\hline Neoseiulus baraki (Athias-Henriot) & 603 & 931 & 176 \\
\hline N. paspalivorus (De Leon) & 29 & 3 & 176 \\
\hline N. recifensis Gondim Jr. \& Moraes & 1 & 7 & 5 \\
\hline Typhlodromus (Anthoseius) ornatus (Denmark \& Muma) & 2 & - & - \\
\hline \multicolumn{4}{|l|}{ Tarsonemidae } \\
\hline Steneotarsonemus concavuscutum Lofego \& Gondim Jr. & 529 & 83 & 6 \\
\hline Steneotarsonemus furcatus DeLeon & 86 & 95 & 385 \\
\hline aff. Tarsonemus & 1 & 25 & - \\
\hline \multicolumn{4}{|l|}{ Tydeidae } \\
\hline Lorryia sp. & 83 & 76 & 13 \\
\hline Metapronematus sp. & 3 & - & - \\
\hline Total & 474,551 & 362,876 & 380,813 \\
\hline Species richness $(\mathrm{S})^{1}$ & $19 \mathrm{a}(14.94-23.05)$ & $19 \mathrm{a}(14.95-23.04)$ & $17 \mathrm{a}(15.07-18.93)$ \\
\hline
\end{tabular}

${ }^{1}$ Means followed by the same letters are not statistically different, as determined by overlapping $95 \%$ confidence interval (in parentheses).

Mounford similarity index: $I=2 j / 2 a b-(a+b) j$, where $a=$ number of species in habitat $A, b=$ number of species in habitat $B$ and $\mathrm{j}=$ number of species found in both habitats. 
relation to mite species composition. The highest similarity was observed between Itamaracá and Pitimbu (index: $19.7 \%$ ), whereas the lowest similarities were observed between each of those localities and Maragogi (for both, index: $12.4 \%$ ).

Very few species found in this study corresponded to groups consisting mainly or exclusively of phytophagous feeding habits (Eriophyidae - Aceria, Tarsonemidae Steneotarsonemus, Tydeidae - Lorryia). The majority of the species collected belonged to groups that have predation as prevailing feeding habit (Ascidae, Bdellidae, Cheyletidae, Phytoseiidae, Tydeidae - Metapronematus). Other species belonged to groups that predominantly have microphytophagous or omnivorous feeding habits (Acaridae, Ebertiidae, Histiostomatidae, Tarsonemidae Aff. Tarsonemus).

A total of 1,218,240 mites were collected; $1,214,421$ of those were A. guerreronis. Other relevant phytophagous mites collected were Steneotarsonemus furcatus De Leon and Steneotarsonemus concavuscutum Lofego \& Gondim Jr. The former was reported as a damaging species on coconut in Brazil (Navia et al. 2005, Lawson-Balagbo et al. 2007), Costa Rica, Cuba, El Salvador, Puerto Rico and Venezuela (Howard et al. 1990, Ochoa et al. 1991, Smiley et al. 1993, Torre et al. 2005), while the latter is only known from Brazil (Lofego \& Gondim Jr. 2006, Lawson-Balagbo et al. 2007). Similarly to A. guerreronis, those tarsonemids cause necrosis on the surface of the nuts. However, while the areas attacked by S. furcatus (Navia et al. 2005) and $S$. concavuscutum (our observation) correspond to transversal necrotic bands on the fruit, the area attacked by $A$. guerreronis is most often triangular, with one of the sides of the triangle parallel to the margin of the perianth. S. furcatus was most abundant in Pitimbu $(1.1 \pm 0.58$ mites per fruit), whereas $S$. concavuscutum was most abundant in Maragogi ( $1.5 \pm 0.75$ mites per fruit). Both species occurred in low population levels in Itamaracá $(0.3 \pm 0.15$ and $0.3 \pm$ 0.22 mites per fruit, respectively).

A total of 2,162 specimens of predatory mites were found. Phytoseiidae was the predominant family, corresponding to $95 \%, 97 \%$ and $82 \%$ of the total numbers of predators collected in Maragogi, Itamaracá and Pitimbu, respectively. Most of the phytoseiids belonged to the genus Neoseiulus. Ascidae was the second most numerous family, corresponding to $4 \%, 3 \%$ and $8 \%$ of the total numbers of predators collected in those respective localities.

The most abundant phytoseiid was Neoseiulus baraki (Athias-Henriot). About 92\%, 97\% and 45\% of the phytoseiids collected in Maragogi, Itamaracá and Pitimbu, respectively, belonged to that species. Neoseiulus paspalivorus (De Leon) was the second most abundant phytoseiid, with most of the specimens been collected in Pitimbu (45\%). The numbers of N. paspalivorus collected in Maragogi and Itamaracá corresponded to $0.5 \%$ and $0.3 \%$, respectively. Those data indicate a negative correlation between the levels of $N$. baraki and $N$. paspalivorus.

Both N. baraki and N. paspalivorus are small, flat, and have relatively short limbs. They seem morphologically adapted to living in restricted spaces, as between the bracts and the surface of the fruits beneath it. Other phytoseiid species reported in this study could actually be on fruits whose bracts were further apart from its surface than usual, or on fruits also damaged by other organisms that opened entrances to the habitat occupied by A.guerreronis. Another possibility is that those mites were mainly on the surface of the fruits, moving underneath the perianth during the evaluations in the laboratory.

The variation of the population density of $A$. guerreronis over time was relatively small in all localities, compared to variations commonly observed in the field for other damaging organisms (Fig. 1). The average number of $A$. guerreronis per 10 fruits varied between 9,260 and 18,680 in Maragogi, 6,430 and 12,140 in Itamaracá and 6,920 and 16,440 in Pitimbu. This relatively low variation was at least in part related to the very stable temperature and air relative humidity levels registered at each site, which were never extreme enough to determine significant reduction in the population of the mites, as well as, to the stable quality of the feeding substrate on which $A$. guerreronis was sampled.

No significant correlations were observed between the levels of abiotic factors (temperature, air humidity and precipitation) and the population levels of $A$. guerreronis in the multiple regression analysis $\left(\mathrm{F}_{3,32}=1.68 ; \mathrm{P}=0.1923\right)$. In addition, no significant correlations were observed between the levels of each of those factors and the population levels of phytoseiids ( $\mathrm{P}>0.05)$, as well as between the former levels and the population levels of A. guerreronis $(\mathrm{P}>0.05)$. Those results could be expected for different reasons. One possible reason seems to be the simultaneous effects of multiple factors on the populations of phytoseiids and $A$. guerreronis in the field, none of which strong enough to overcome possible compensating effects of other factors and determine the pattern of fluctuation of that population. In addition, the environmental factors measured in this study (of the macro-habitat) may be quite different from those prevailing underneath the bracts (not measured in this study), where phytoseiids and A. guerreronis were sampled. Non significant correlations between climatic factors and the population of $A$. guerreronis were also reported by Howard et al. (1990) in studies conducted in Puerto Rico and Florida and by Ramaraju et al. (2002) and Varadarajan \& David (2002) for studies conducted in Índia.

In Itamaracá, the highest level of phytoseiids occurred a month after A. guerreronis reached the highest level, whereas in Maragogi the highest levels of both phytoseiids and A. guerreronis occurred simultaneously in the same month (Fig. 1). Those results suggest that the phytoseiids may play an important role as predadors of $A$. guerreronis under the bracts of coconut. Fernando et al. (2003) also reported the highest levels of phytoseiid predators on coconut in Sri Lanka a month after A. guerreronis reached the highest level.

The observed fluctuation of the populations of $A$. guerreronis and phytoseiid predators in this study did not allow the determination of the efficiency of the latter in controlling the former in any of the fields. However, this should not be taken as an indication of the inefficiency of the predators. It may be possible that the predators need 

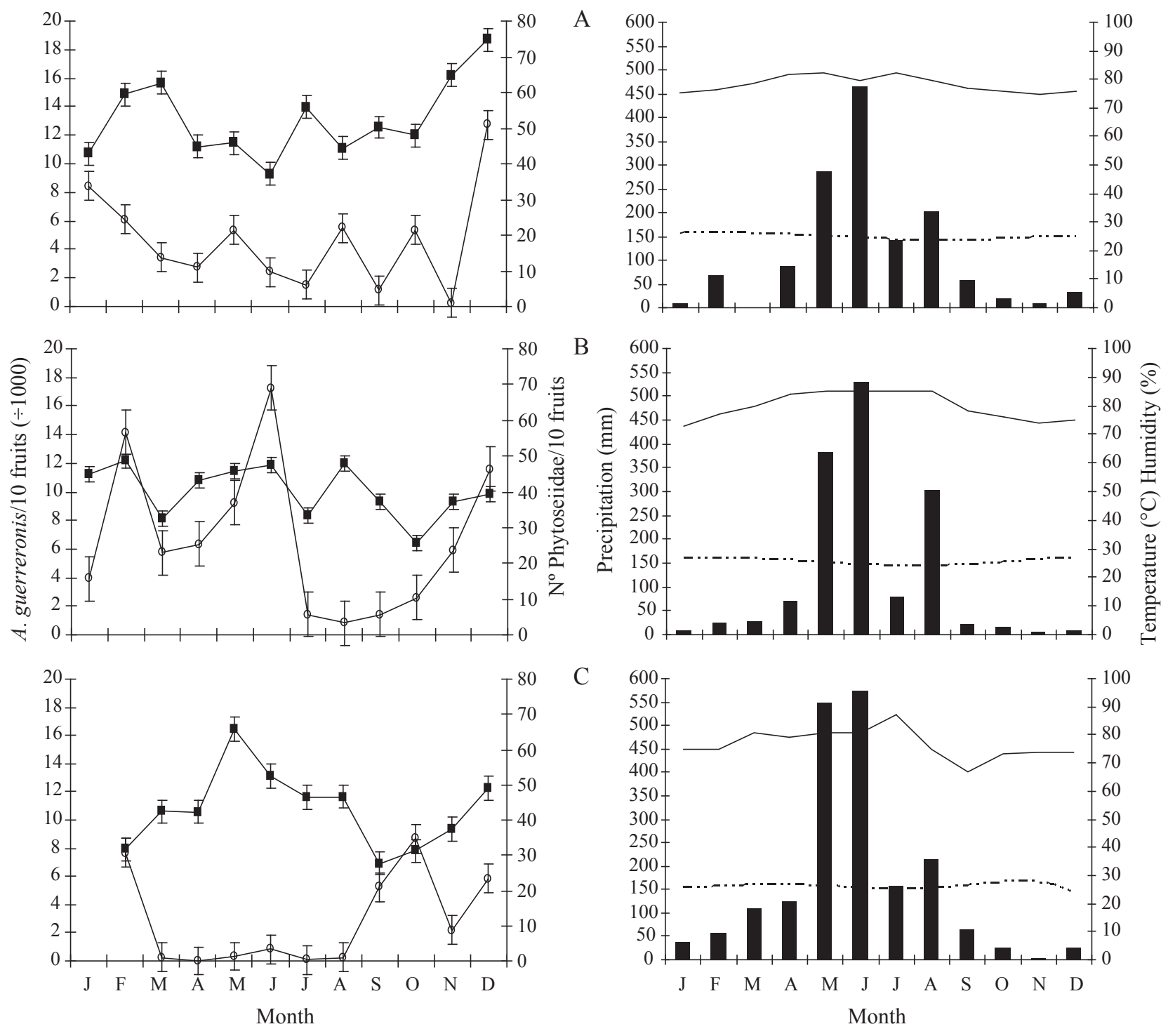

$\mathrm{C}$

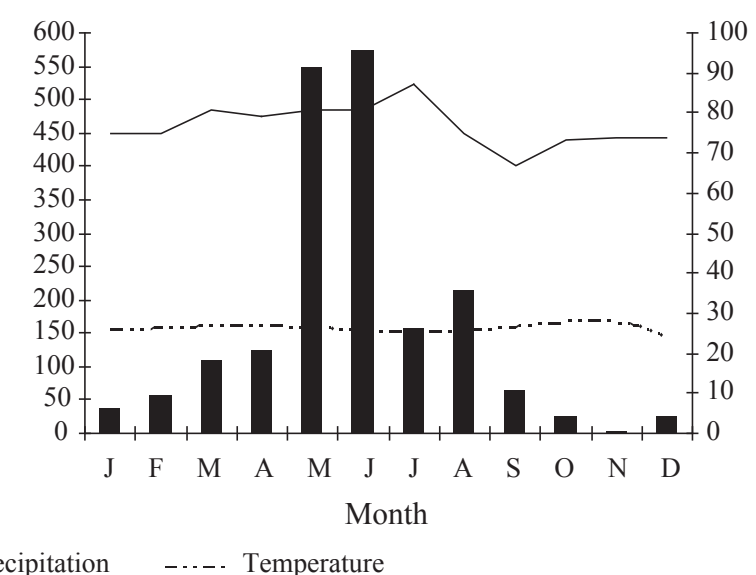

$\rightarrow$ Phytoseiidae Humidity

Fig. 1. Mean numbers (and corresponding standard errors) of A. guerreronis and predaceous Phytoseiidae mites per 10 fruits of C. nucifera, as well as monthly precipitation $(\mathrm{mm})$, monthly average temperature $\left({ }^{\circ} \mathrm{C}\right)$ and air relative humidity $(\%)$ in Maragogi AL (A), Itamaracá - PE (B) and Pitimbu - PA (C).

some more time on the plants to build up their populations in order to have an impact on the pest. It seems possible that sampling of slightly older fruits, at least 5-6 months old, could probably allow a better determination of the affect of the predators.

Studies on population dynamics of $A$. guerreronis and its predators were conducted in India (Ramaraju et al. 2002), Sri Lanka (Fernando et al. 2003) and Benin (Negloh et al. manuscript in preparation), but not in the Americas. The species of predators most often associated with $A$. guerreronis in this study ( $N$. baraki, $N$. paspalivorus, Amblyseius largoensis (Muma), Bdella distincta (Bake \& Balogh) and Proctolaelaps bickleyi (Bram)) have also been reported in studies conducted in other countries (Howard et al. 1990, Fernando et al. 2002, Ramaraju et al. 2002, Moraes et al. 2004) and most recently in a extensive survey in northern and northeastern Brazil (Lawson-Balagbo et al. 2007). However, the relation between these predators and the population of $A$. guerreronis needs further evaluation. Studies on biology and predation capacity of the predators prevailing on coconut need to be conducted, to determine the possibility of their practical use for the control of $A$. guerreronis. Studies conducted by Lawson et al. (2007) showed that two of those species, A. largoensis and Neoseiulus recifensis Gondim Jr. \& Moraes, the latter also found under the coconut bracts, are frequently encountered on leaves of palm trees (Gondim Jr. \& Moraes 2001), where they can feed on dispersing A. guerreronis. 


\section{Acknowledgments}

To J.B. Torres (UFRPE, Recife, Brazil) for his great help with the analysis of the data. This work was supported in part with funds from $\mathrm{CNPq}$ (Conselho Nacional de Desenvolvimento Científico e Tecnológico) and special project funds provided to IITA (International Institute of Tropical Agriculture) by the Austrian Ministry of Finance through Austrian-CGIAR funding.

\section{References}

Aquino, M.L.N., C.H.W. Flechtmann \& G.P. Arruda. 1968. Contribuição ao estudo do ácaro causador da necrose do olho do coqueiro em Pernambuco e seu controle. Recife, IPA, 17p. (Boletim Técnico, 34).

Cabrera, R.I., C.G. Otero \& N. Rodriguez. 1992. Principales enemigos naturales del cocotero Aceria guerreronis (Eriophyidae) en Cuba. Agrociência. Ser. Protec. Veg. 3: 83-89.

Colwell, R.K. 2004. EstimateS - Statistical estimation of species richness and shared species from samples. Version 7 User's guide and applications Published at: http://purl.oclc.org/ estimates.

Fernando, L.C.P., I.R. Wickramananda \& N.S. Aratchige. 2002. Status of coconut mite, Aceria guerreronis, in Sri Lanka, p.1-8. In L.C.P. Fernando, G.J. Moraes \& I.R. Wickramananda (eds.), Proceedings of the International Workshop on Coconut Mite (Aceria guerreronis). Sri Lanka, Coconut Research Institute, 117p.

Fernando, L.C.P., N.S. Aratchige \& T.S.G. Peris. 2003. Distribution patterns of coconut mite, Aceria guerreronis, and its predator Neoseiulus aff. paspalivorus in coconut palms. Exp. Appl. Acarol. 31: 71-78.

Gondim Jr., M.G.C., C.H.W. Flechtmann \& G.J. Moraes. 2000. Mite (Arthropoda: Acari) associates of palm (Arecaceae) in Brazil. IV. Descriptions of four new species in the Eriophyidae. Syst. Appl. Acarol. 5: 99-110.

Gondim Jr., M.G.C. \& G.J. Moraes. 2001. Phytoseiid mites (Acari : Phytoseiidae) associated with palm trees (Arecaceae) in Brazil. Syst. Appl. Acarol. 6 : 65-94.

Haq, M.A., K. Sumangala \& N. Ramani. 2002. Coconut mite invasion, injury and distribution, p.41-49. In L.C.P. Fernando, G.J. Moraes \& I.R. Wickramananda (eds.), Proceedings of the International Workshop on Coconut Mite (Aceria guerreronis). Sri Lanka, Coconut Research Institute, 117p.

Howard, F.W., E. Abreu-Rodrigues \& H.A. Dernmark. 1990. Geographical and seasonal distribution of the coconut mite, Aceria guerreronis (Acari: Eriophyidae), in Puerto Rico e Florida, USA. J. Agric. Univ. 74: 144-251.

Lawson-Balagbo, L.M., M.G.C. Gondim Jr., G.J. Moraes, R. Hanna $\&$ P. Schausberger. 2007. Exploration of the acarine fauna on coconut palm in Brazil with emphasis on Aceria guerreronis (Acari: Eriophyidae) and its natural enemies. Bull. Entomol. Res. 98: 83-96.
Lofego, A.C. \& M.G.C. Gondim Jr. 2006. A new species of Steneotarsonemus (Acari: Tarsonemidae) from Brazil. Syst. Appl. Acarol. 11: 195-203.

Moore, D., L. Alexander \& R.A. Hall. 1989. The coconut mite, Eriophyes guerreronis Keifer, in St Lucia yield losses and attempts to control with acaricide, polybutene e Hirsutella fungus. Trop. Pest Manag. 35: 83-89.

Moraes, G.J., P.C. Lopes \& L.C.P. Fernando. 2004. Phytoseiid mites (Acari: Phytoseiidae) of coconut growing areas in Sri Lanka, with descriptions of three new species. J. Acarol. Soc. Jpn. 13: 1-20.

Navia, D., G.J. Moraes, A.C. Lofego \& C.H.W. Flechtmann. 2005. Acarofauna associada a frutos de coqueiro (Cocos nucifera L.) de algumas localidades das Américas. Neotrop. Entomol. 34: 349-354.

Ochoa, R., R.L. Smiley \& J.L. Saunders. 1991. The family Tarsonemidae in Costa Rica (Acari: Heterostigmata). Int. J. Acarol. 17: 41-86.

Ramaraju, K., K. Natarajan, P.C. Sundara Babu, S. Palanisamy \& R.J. Rabindra. 2002. Studies on coconut eriophyid mite, Aceria guerreronis Keifer in Tamil Nadu, Índia, p.13-51. In L.C.P. Fernando, G.J. Moraes \& I.R. Wickramananda (eds.), Proceedings of the International Workshop on Coconut Mite (Aceria guerreronis). Sri Lanka, Coconut Research Institute, 117p.

Robbs, C.F. \& A.L. Peracchi. 1965. Sobre a ocorrência de um ácaro prejudicial ao coqueiro (Cocos nucifera L.), p.65-70. Anais da IX Reunião Fitossanitária, Rio de Janeiro.

Santana, D.L.Q. \& C.H.W. Flechtmann. 1998. Mite (Arthropoda: Acari) associates of palms (Arecaceae) in Brazil. I. Present status and new records. Rev. Bras. Zool. 15: 959-963.

SAS Institute. 1999-2001. SAS/STAT User's guide, version 8.02, TS level 2MO. SAS Institute Inc., Cary, NC.

Silveira Neto, S., O. Nakano, D. Barbin \& N. Villa Nova. 1976. Manual de ecologia de insetos. São Paulo, Agronômica Ceres, $419 \mathrm{p}$.

Siriwardena, P.H.A.P., L.C.P. Fernando \& T.S.G. Peiris. 2005. A new method to estimate a population size of coconut mite, Aceria guerreronis, on a coconut. Exp. Appl. Acarol. 37: 123-129.

Smiley, R.L., C.H.W. Flechtmann \& R. Ochoa. 1993. A new species of Steneotarsonemus (Acari: Tarsonemidae) and an illustrated key to grass-infesting species in the Western hemisphere. Int. J. Acarol. 19: 87-93.

Torre, P. de la, L. Almaguel, E. Botta \& I. Cáceres. 2005. Plantas hospedantes de Steneotarsonemus furcatus De Leon (Acari: Tarsonemidae) en Cuba. Neotrop. Entomol. 34: 517-519.

Varadarajan, M.K. \& P.M.M. David. 2002. Population dynamics of the coconut mite Aceria guerreronis Keifer (Acari: Eriophyidae) and associated arthropods in Tamil Nadu, India. Insect. Sci. Applic. 22: 47-59.

Received 22/XII/06. Accepted 03/VII/08. 